\title{
Government Engineering Colleges in Assam: Current Status and Steps for Improvement
}

Dr Salim Barbhuiya ${ }^{\dagger}$

\section{Abstract}

The State Government has well understood the demand of technical education in the state and attention is focused on rapid development in this field, with global professional standards and international accreditation being recognised as the benchmarks for quality assurance. In this regard, it is important to understand an accord called The Washington Accord. This is an international agreement to ensure consistent quality of undergraduate engineering program across the World. Programs recognised by accrediting authorities in countries that are signatories are considered to be equivalent in terms of quality and the graduate attributes. In 2014, the National Board of Accreditation (NBA) India joined as a signatory for programs accredited by NBA offered by education providers accepted by NBA as Tier 1 institutions. In February 2015, the Government of Assam appointed an expert team from the Faculty of Science and Engineering at Curtin University Australia to conduct an audit of technical education in the public sector. The purpose of the audit was to find the gaps that may exist in governance, curriculum, policies, guidelines and community engagement in relation to those to be required and found in a Washington Accord approved programme. This paper summarises some of the gaps. This is followed by recommendations to improve the technical education sector in Assam. The findings in the gap analysis are the first in a series of steps toward the long-awaited restructuring of the technical higher education sector in the state of Assam. It is now up to the Government of Assam to take the necessary steps in addressing the issues to reenergise the technical higher education sector and bring the public technical colleges to the forefront of quality Indian institutions offering international standard engineering education and infrastructure.

Keywords: National Board of Accreditation, Washington Accord, Graduate Attributes, Curriculum Mapping, Assessment Review

\footnotetext{
' Lecturer, School of Civil Engineering, University of Leeds, United Kingdom, Email: S.Barbhuiya@leeds.ac.uk (C) 2020 Barbhuiya. This is an Open Access article distributed under the terms of the Creative Commons Attribution License (http://creativecommons.org/licenses/by/2.0), which permits unrestricted use, distribution, and reproduction in any medium, provided the original work is properly cited.
} 


\section{Introduction}

Assam has five Government engineering colleges: Assam Engineering College (AEC) at Guwahati, Jorhat Engineering College (JEC) at Jorhat, Bineswar Brahma Engineering College (BBEC) at Kokhrajar, Barak Valley Engineering College (BVEC) and Jorhat Institute of Science and Technology (JIST) at Jorhat. Assam Engineering College ( $A E C)$, the first Engineering College in North-east India, was established in Guwahati in 1955. The College started with the Civil Engineering department, and within a few years, other engineering departments were started. Presently, it awards a Bachelor in Engineering degrees in eight different engineering disciplines, Master in Engineering degrees in Civil, Mechanical and Electrical Engineering, and a Master in Computer Application degree. The College offers PhD programs under all departments. All the courses of AEC are affiliated to Gauhati University.

Jorhat Engineering College (JEC) is the second Government Engineering College of Assam. The College started functioning with the admission of its first batch of students in Civil Engineering in 1960. The College currently offers AICTE recognised $\mathrm{BE}$ courses in Civil, Electrical, Mechanical, Computer Science \& Engineering and Instrumentation Engineering and ME course in Mechanical Engineering, Civil Engineering and Electrical \& Instrumentation Engineering. All the courses of AEC are affiliated to Dibrugarh University.

Bineswar Brahma Engineering College (BBEC) was established in 2008 at Kokrajhar. The College is affiliated to Gauhati University and is accredited by AICTE. Jorhat Institute of Science and Technology (JIST) offers three years bachelor degree in science (Physics, Chemistry, Mathematics and Information Technology) along with two BE Courses in Electronics \& Telecommunication Engineering, Power Electronics \& Instrumentation Engineering. Formerly the Institute was known as Science College Jorhat. In 2008 Government of Assam, upgraded the College and renamed it as Jorhat Institute of Science and Technology registered under Societies Registration Act. The Institute is affiliated to Dibrugarh University.

Barak Valley Engineering College (BVEC) is the first state government engineering college in the Barak valley region of Assam, and it is the fifth state engineering college. The noble initiative for setting up this engineering college was taken in the year of 2009 by the Government of Assam. It started its full-fledged operation in 2017 under the purview of the Directorate of Technical Education (DTE), Assam. The college campus is connected to the National Highway by PWD rural roads.

Against this backdrop, this study is an attempt to critically discuss the current status of the government Engineering Colleges in Assam and the ways for its improvement. It begins with a brief discussion of the Washington Accord, which is considered as the benchmark of quality assurance in technical Institutes. Following this, it discusses the strengths and weaknesses of the Engineering Colleges of Assam and the ways for its amelioration.

\section{The Washington Accord: Graduate Attributes and Competencies}

The Washington Accord is an international agreement to ensure consistent quality of undergraduate engineering program across the World. Programs recognised by accrediting authorities in countries that are signatories are considered to be equivalent in terms of quality and the graduate attributes. In 2014, the National Board of Accreditation (NBA) India joined as a signatory for programs accredited by NBA offered by education providers accepted by the NBA as Tier 1 institutions. The Graduate Attributes, as defined in the Accord are a set of individually assessable outcomes, that are the components indicative of the graduate's potential to acquire competence to practice at the appropriate level (clear, succinct, measurable statements of the expected capability, qualified if necessary by a range of indication appropriate to the type of the program). More specifically, the Washington Accord graduate attributes are: 
- Engineers with core knowledge in a discipline

- Technically competent

- Able to carry out problem analysis and design and development of solutions

- Competent in modern tool usage

- Aware of the Engineer and the Society, the Environment and Sustainability

- Capable of demonstrating high level of Ethics

- Able to perform individually and in a team

- Versatile in professional communication
- Demonstrate knowledge of engineering management and economics

- Willing to be a life-long learner

This set of attributes is the minimum requirements for a graduate from the programs and vary slightly from individual signatoryadopted versions to reflect local context or a higher set of competencies. The example of documents or evidence to evaluate programs in the state government Engineering colleges of Assam is shown in Table 1 . The research questionnaire is summarised in Table 2.

\begin{tabular}{|c|c|}
\hline Area & Examples of Documents or Evidence Sought \\
\hline Organisational Structure & $\begin{array}{l}\text { - Institutional/College or Departmental strategic plan. } \\
\text { - } \quad \text { Onnual plan(s) with details of Knowledge Performance Index } \\
\text { - } \quad \text { Delegation of authority policy and schedules. } \\
\text {-Teaching and Learning" plan. } \\
\text { - Orientation and induction policy and schedules for new staff. } \\
\text { - Agenda or minutes of meetings where professional aspects of } \\
\text { engineering, the academic framework and development of } \\
\text { strategy to address or improve engineering education are } \\
\text { addressed. }\end{array}$ \\
\hline Academic and Support Staff Profile & $\begin{array}{l}\text { - List of staff with their approved and completed qualifications } \\
\text { and professional accreditation data and what level of unit they } \\
\text { teach. } \\
\text { - Student staff ratio data } \\
\text { Job profiles for various levels, including technical and } \\
\text { administrative support. } \\
\text { - Workload management policy. } \\
\text { - Professional development policy and evidence of types of } \\
\text { - } \text { Registration in professional bodies policy. } \\
\text { - Industry Experts used - data such as what for, frequency, the } \\
\text { extent of involvement and input. }\end{array}$ \\
\hline $\begin{array}{l}\text { Academic Leadership and Educational } \\
\text { Culture }\end{array}$ & $\begin{array}{l}\text { - } \quad \text { Quality assessment and continuous improvement policy. } \\
\text { - } \quad \text { Records/minutes relating to quality assessment } \\
\text { - } \quad \text { Policy regarding industry advisory board(s). } \\
\text { - } \quad \text { Records of Industry advisory board meetings. } \\
\text { - } \quad \text { Records of practical experience such as fieldwork } \\
\text { - } \quad \text { Lists or evidence of publications. } \\
\text { - } \quad \text { Documented analysis of the achievement of learning outcomes, } \\
\text { - } \quad \text { Eviduate Destination Survey(s) and market analysis. } \\
\text { - }\end{array}$ \\
\hline Student Profile & $\begin{array}{l}\text { Strategic plans and/or business plans with evidence of: } \\
\text { - } \quad \text { Physical infrastructure or premises to accommodate student } \\
\text { - } \quad \text { Student recruitment information. } \\
\text { - Staff recruitment to maintain academic staff levels. } \\
\text { - Provision of facilities and equipment and services to support } \\
\text { - } \quad \text { the student load. } \\
\text { - Comparative data. }\end{array}$ \\
\hline $\begin{array}{l}\text { Accreditation and Pathways and } \\
\text { Program Structure }\end{array}$ & $\begin{array}{l}\text { - Policies for recognising previous/prior learning } \\
\text { - Articulation agreements. }\end{array}$ \\
\hline
\end{tabular}




\begin{tabular}{|c|c|}
\hline & $\begin{array}{l}\text { - Examples of articulation agreements and CRL "maps". } \\
\text { - Examples of governance, control, audit and quality assurance } \\
\text { for articulation and CRL. } \\
\text { - Evidence of consistency. }\end{array}$ \\
\hline The Student Experience & $\begin{array}{l}\text { - } \quad \text { Course/program literature, marketing material. } \\
\text { - } \quad \text { learning. } \\
\text { - } \quad \text { Evidence of employer involvement in student experience. } \\
\text { - } \quad \text { Studence of student and stakeholder input into decisions. } \\
\text { improving trend. } \\
\text { - Data showing improving retention, progress rates and } \\
\text { completion. }\end{array}$ \\
\hline $\begin{array}{l}\text { Funding and Financial Management } \\
\text { including resource availability to } \\
\text { support curriculum delivery and } \\
\text { efficacy }\end{array}$ & $\begin{array}{l}\text { - } \quad \text { Financial management and budget planning documents. } \\
\text { - } \quad \text { Evidence of consultation and planning with educational } \\
\text { - } \quad \text { Financial planning for teaching essentials, resources, materials, } \\
\text { and technologies. } \\
\text { - } \text { Risk identification and mitigation. } \\
\text { - Disaster recovery plan. }\end{array}$ \\
\hline $\begin{array}{l}\text { Specification of Educational } \\
\text { Outcomes and Curriculum Mapping }\end{array}$ & $\begin{array}{l}\text { Documentation of program objectives targeted graduate } \\
\text { capabilities and the educational design philosophy as well as } \\
\text { the associated mapping. } \\
\text { - Program handbooks and records. } \\
\text { - } \text { Academic unit guidelines. } \\
\text { - Examples of communication with stakeholders. }\end{array}$ \\
\hline $\begin{array}{l}\text { Governance and formal processes for } \\
\text { development, approval, and ongoing } \\
\text { amendment }\end{array}$ & $\begin{array}{l}\text { - } \quad \text { Committee documents, terms of reference, minutes. } \\
\text { - } \quad \text { Organisational charts. } \\
\text { - Bulletins or other notification methodologies. }\end{array}$ \\
\hline $\begin{array}{l}\text { Consultation with stakeholders, } \\
\text { continuous review and improvement } \\
\text { processes }\end{array}$ & $\begin{array}{l}\text { - } \quad \text { Committee structures and membership. } \\
\text { - } \quad \text { Samples of surveys and consultations. } \\
\text { - Evidence of feedback. }\end{array}$ \\
\hline $\begin{array}{l}\text { Processes for setting and reviewing } \\
\text { educational outcomes }\end{array}$ & $\begin{array}{l}\text { - Cyclic review documents. } \\
\text { - } \quad \text { Teaching and Learning Plan. } \\
\text { (similar to Assessment Quality Panels [AQP], Annual Course } \\
\text { review, Individual unit reviews, peer review, benchmarking, } \\
\text { ART process etc.). } \\
\text { - Survey results (such as Curtin's eVALUate. CASS, CEQ, UES for } \\
\text { example). } \\
\text { "Closing the loop" or feedback evidence. }\end{array}$ \\
\hline $\begin{array}{l}\text { Educational design and Assessment } \\
\text { Review }\end{array}$ & $\begin{array}{l}\text { - Evidence of program objectives and targeted graduate } \\
\text { outcomes in course materials. } \\
\text { - Assessment design reflects a diversity of assessment } \\
\text { types/modes. } \\
\text { - Open-ended assignments and research capacity development. } \\
\text { - } \quad \text { Infories and regulations to manage academic integrity. } \\
\text { - Evidence of consistent and appropriate assessment monitoring } \\
\text { and external benchmarking }\end{array}$ \\
\hline $\begin{array}{l}\text { Benchmarking and } \\
\text { processes for review and revision of } \\
\text { existing program(s) }\end{array}$ & $\begin{array}{l}\text { Evidence of benchmarking exercises, inter-institutional review, } \\
\text { industry consultation, and student feedback, local or national } \\
\text { reviews/surveys. }\end{array}$ \\
\hline Administration and support & $\begin{array}{l}\text { - } \quad \text { Functional organisational charts. } \\
\text { - } \quad \text { Delegated authority notification. } \\
\text { - } \quad \text { Enticy and regulation documents. }\end{array}$ \\
\hline
\end{tabular}




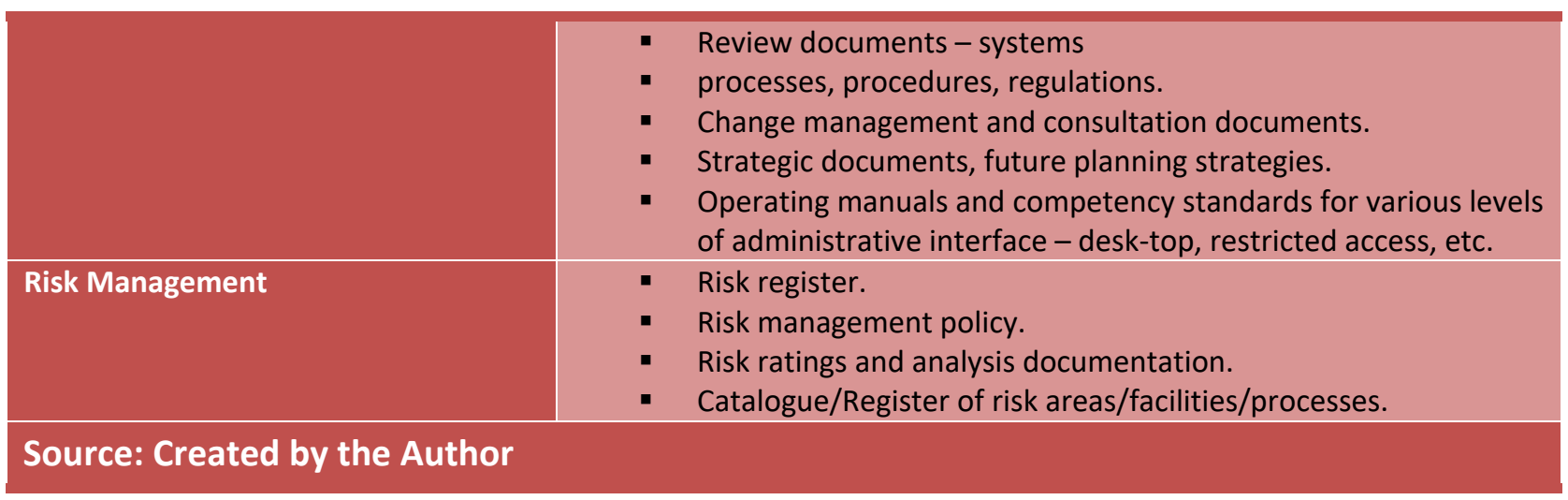

\begin{tabular}{|c|c|c|c|c|c|c|}
\hline & 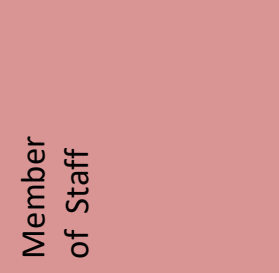 & 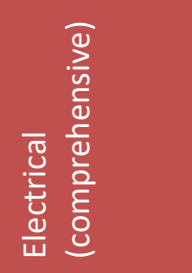 & 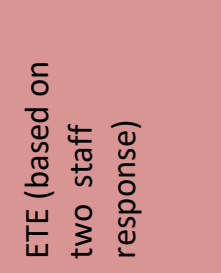 & 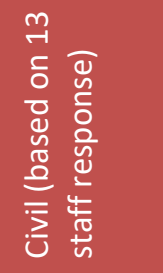 & 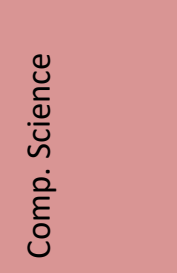 & 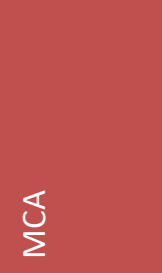 \\
\hline $\begin{array}{l}\text { No. of Academic Staff } \\
\text { in the Department? }\end{array}$ & $\begin{array}{l}8 \text { full time } \\
3 \text { part time }\end{array}$ & $\begin{array}{l}\text { Regular :17, } \\
\text { Guest } \\
\text { Faculty: } 2 .\end{array}$ & 4 & 20 & $\begin{array}{l}4 \mathrm{ETE}+3 \\
\mathrm{CSE}\end{array}$ & 7 \\
\hline No. of Staff with PhD? & 5 & 11 & 1 & 13 & - & 2 \\
\hline No. of Technical Staff? & $\begin{array}{l}4 \text { full time } \\
1 \text { part time }\end{array}$ & 4 & 4 & 10 & $\begin{array}{l}4 \mathrm{ETE}+1 \\
\mathrm{CSE}\end{array}$ & 5 \\
\hline $\begin{array}{l}\text { No. of Technical } \\
\text { Papers Past Five Years } \\
\text { (international journal, } \\
\text { local journal, } \\
\text { conference) }\end{array}$ & $\begin{array}{l}12 \text { internationals } \\
0 \text { local } \\
6 \text { conference }\end{array}$ & $\begin{array}{l}18 \text { Inter } \\
0 \text { local } \\
8 \text { conf }\end{array}$ & $\begin{array}{l}1 \text { Inter } \\
0 \text { local } \\
6 \text { conf }\end{array}$ & $\begin{array}{l}33 \text { Inter } \\
32 \text { local } \\
119 \text { conf }\end{array}$ & Nil & $\begin{array}{l}34 \text { Interl } \\
0 \text { local } \\
4 \text { conf }\end{array}$ \\
\hline $\begin{array}{l}\text { No of Research } \\
\text { Projects in the Last } \\
\text { Five Years }\end{array}$ & 2 & 0 & 1 & 12 & Nil & $\begin{array}{l}1 \text { AICTE } \\
\text { RPS } \\
\text { Project }\end{array}$ \\
\hline $\begin{array}{l}\text { Total Research } \\
\text { Funding in Last Five } \\
\text { Years }\end{array}$ & Rs. $3,500,000$ & 0 & Rs 500,000 & $\begin{array}{l}\text { Rs } \\
9,750,000\end{array}$ & Nil & $\begin{array}{l}\text { Rs } \\
1,250,000\end{array}$ \\
\hline $\begin{array}{l}\text { No. of PhD / MPhil. } \\
\text { Students }\end{array}$ & $3 \mathrm{PhD}$ & $\begin{array}{l}\text { Yes } \\
\text { (number } \\
\text { not } \\
\text { specified) }\end{array}$ & $6 \mathrm{PhD}$. & $\begin{array}{l}\text { PhD: } 14 \\
\text { ME: } 8\end{array}$ & 0 & PhD: 4 \\
\hline $\begin{array}{l}\text { No. of Travel Grants in } \\
\text { the Past Five Years to } \\
\text { Attend } \\
\text { International/National } \\
\text { Level Conferences? }\end{array}$ & 0 & 0 & 0 & 4 & 0 & 2 \\
\hline $\begin{array}{l}\text { If there were Funding } \\
\text { Available, What } \\
\text { Project you could do } \\
\text { that will be of Direct } \\
\text { Benefit to the State of } \\
\text { Assam? }\end{array}$ & $\begin{array}{l}\text { Tea, Coal, Energy, } \\
\text { Waste } \\
\text { management }\end{array}$ & $A^{*}$ & $\mathrm{~B}^{*}$ & $\mathrm{C}^{*}$ & $\begin{array}{l}\text { Processor- } \\
\text { based } \\
\text { electronic } \\
\text { control }\end{array}$ & $\mathrm{D}^{*}$ \\
\hline $\begin{array}{l}\text { Which Industry Exists } \\
\text { in Assam that you } \\
\text { could Engage with? }\end{array}$ & $\begin{array}{l}\text { Tea, Oil, Paper, } \\
\text { Fertilizer }\end{array}$ & $\begin{array}{l}\text { Power } \\
\text { industry, } \\
\text { Tea } \\
\text { industry, oil } \\
\text { industry, }\end{array}$ & $\begin{array}{l}\text { Central/ } \\
\text { State (Assam) } \\
\text { Govt. initially, } \\
\text { later on with }\end{array}$ & $E^{*}$ & None & None. \\
\hline
\end{tabular}




\begin{tabular}{|c|c|c|c|c|c|c|}
\hline & & $\begin{array}{l}\text { sericulture } \\
\text { industry } \\
\text { etc. }\end{array}$ & $\begin{array}{l}\text { some start- } \\
\text { ups }\end{array}$ & & & \\
\hline $\begin{array}{l}\text { What is the Biggest } \\
\text { Barrier to Research in } \\
\text { your Opinion? }\end{array}$ & $\begin{array}{l}\text { Infrastructure and } \\
\text { Funds }\end{array}$ & N/A & $\begin{array}{l}\text { Environment/ } \\
\text { Money/ } \\
\text { Incentive } \\
\text { (recognition) }\end{array}$ & $\mathrm{F}^{*}$ & $\begin{array}{l}\text { Work } \\
\text { Overload }\end{array}$ & $\mathrm{G}^{*}$ \\
\hline $\begin{array}{l}\text { What Research } \\
\text { Equipment or } \\
\text { Software you have } \\
\text { Access to for } \\
\text { Research? }\end{array}$ & $\begin{array}{l}\text { UV } \\
\text { spectrophotometer, } \\
\text { Atomic Absorption } \\
\text { Spectrometer, Gas } \\
\text { Chromatograph }\end{array}$ & $\begin{array}{l}\text { Software } \\
\text { related to } \\
\text { Power } \\
\text { System, } \\
\text { MATLAB } \\
\text { etc. }\end{array}$ & $\begin{array}{l}\text { Simulators/ } \\
\text { tools for } \\
\text { signal/ image } \\
\text { processing }\end{array}$ & $\mathrm{H}^{*}$ & $\begin{array}{l}\text { Labview, } \\
\text { MATLAB }\end{array}$ & $I^{*}$ \\
\hline
\end{tabular}

Notes:

A. Project on power system monitoring and operation, project related to sericulture industry of Assam, project related to the tea industry of Assam and others.

B. A real-time surveillance system (day/night) using image processing for protecting rhinos from the poacher. Comprehensive solution/model with technical solutions for smart city and smart village in the state considering local aspects. Monitoring and remediation of air and water pollutants.

C. Establishment of "Materials Testing and Research Centre. Determining soil sites susceptible to liquefaction in Guwahati City. Alternate materials for Traditional Housing- 'Assam Type Housing' for the State of Assam with Earthquake Resistant properties through laboratory testing and Numerical Modeling. Rainfallrunoff studies, River meandering; Irrigation water application methods. Bank Erosion Prediction, Flood early warning system,
Suitability of Geobag as a bank protection material. Integrated planning for basin development Optimal planning of a reservoir system. River training, bank protection and flood mitigation. Landslide Project, Liquefaction. Potential Study, Slope stability study, Road development and traffic problem study in Guwahati, River Bank Erosion study, Geo-engineering investigation, an alternative source of aggregates for the construction of roads \& building. Foundation behaviour during an earthquake. Study of Producing of High-grade concrete. The project related to the increase in the water holding capacity of the soil (sandy) using different geomaterials like fly ash so that it will help in crop production in Assam. Study on Scour depth evaluation and protection against scour. Study of climate changes. Earthquake Hazard Mapping, Site Response Analysis, Soil Bio-Engineering, Alternative construction materials, 
Sustainable planning of Urban /Rural infrastructure.

D. No fund is available. I am proposing to solve the traffic problem of Guwahati using graph theory. Already one research scholar has conducted a few works on this topic.

E. NEEPCO, CPWD, NHPC etc. AAI, NF Railway, NHAI, PWD. State Water Resources Department, Brahmaputra Board, NESAC, NIH, ICAR, APGCL etc. Soil Industrial for Seismic Assessment of their Infrastructure Construction Industry. Assam Power Generation Corporation Limited, North East Power Corporation Limited. Construction industry for petrographical investigation. The thermal power plants that produce fly ash. Road, Infrastructure.

F. Lack of State Government funding for research work. Excellent laboratory facilities are not present, and the College remains open only up to $4 \mathrm{pm}$. Lack of Physical infrastructure for cutting edge research. Lack of clear policy on research activity. Lack of mobility to networking and expand research interest \& activity. Non- availability of sufficient Literature, non-availability of certain types of equipment. Lack of large researchfunding from State/ Central Govt., Lack of infrastructure facilities like power, space etc. in the College, Library/online journal facilities. Lack of state-of-theart laboratory facilities. Lack of laboratory facilities as I am mainly concentrating on experimental works. Availability of Literature, funding Lack of fund and modern equipments for testing, Software. Lack of Journal, Lack of Sophisticated Lab. Equipment in Lack of Fund. The Institute does not have proper laboratory facilities. There is a need for proper laboratory technicians who can help in laboratory activities. Moreover, regular funding is required to keep the equipments in working condition. Lack of infrastructure. Availability of Literature, funding.

G. In my opinion, there are many barriers in research, quite a few of them are not getting funding properly, not getting proper laboratory, say one of the important research area is VLSI design but not proper laboratory or other equipments for it. There are more such areas which are to be explored yet.

H. Software: STAAD, SAP 2000, ANSYS etc. SLOPE W, Same equipments that are used for UG and PG level. Structural Engineering Software SELENA, ETAB, MATLAB, MIC3, Road Max, SlopeW. PLAXIS-2D, MIKE 21C, ArC GIS, Erdas Imging Equipment: GPS, AWS, Large size lab. Flumes etc. Artificial laboratory channels, Ecosounder, LINDO, GeoSlope. Software - Some equipments that are used for routine geotechnical tests. Normal testing equipments. 
I. One Blade Server and many Software related to my research areas. In future, I am thinking to install a VLSI research lab

\section{Weaknesses in the Governance Model}

Assam technical education institutions are plagued by a bureaucracy that constrains academic and operational capacity. Currently, the system at best could be described as passive, not proactive. Colleges cannot appoint their own staff, and a significant percentage of sanctioned posts are vacant. There is intense negativity about their ability to modernise equipment, facilities, and to initiate self-development. Staff development, systematic resource building and academic progression to reward performance are non-existent. There is an evident lack of institutional planning: goals to achieve in the short, medium and long-term are missing. Robust policies for various academic functions including policies and guidelines for assessment, disciplinary measures, quality review and improvement need to be in place. The dedication and passion for academia are clearly visible among both staff and students, and the presence of a sound governance structure would do dramatically assist the Engineering Colleges in establishing themselves as academic institutions offering internationally accredited programs.

\section{Curriculum Development, Delivery and Review}

Current curriculum offered by the Colleges is prescribed by the All India Council for Technical Education (AICTE). While the content is relevant, it lacks a contemporary touch. In most cases, the curriculum appears not have been reviewed in the past few years, even though there is a provision of a review every five years leaving the curriculum static rather than dynamic. Lack of industry input and the absence of a mechanism for Industry to engage are apparent. Learning units are merely staggered to form a curriculum rather than being structured ways of unit learning outcomes building towards year-level outcomes and then to course learning outcomes relating to graduate attributes. Connectivity and progress to completion are absent. Furthermore, the curriculum lacks critical topics such as Engineering Ethics, Professional Practice and Sustainability. Organisationally, there are no written policies on curriculum design, program educational objectives, program learning outcomes, changes to curriculum content or requirements, external review or cyclic review, benchmarking, quality assessment or assessment of learning quality.

\section{Access to Modern Tools and Equipment}

Most teaching venues in the Engineering colleges of Assam are traditional "Chalk and Talk" environments. If a student misses a lecture, it is not clear how he/she may access this other than to rely on peer support. Libraries are poorly resourced; computing resources are inadequate and not reflective of modern technology or trends. Laboratory equipment is old, and its calibration, accuracy and repeatability of results are questionable. Technical support is also not adequate. The equipment is visibly aged and not suitable at all for research projects. Students are unlikely to carry over equipment training undertaken at the Colleges to the modern workplace. Many excellent modern teaching tools including essential internet, Wi-Fi, digital journals and ebooks, and specialised Software are not available.

\section{Assessment Design and Review}

There is an inadequate pedagogical design of the assessment regime leading to outcomes that are not fit for purpose in many cases. Students receive little or no feedback. There are no annual course reviews, no quality panels, no written policies, guidelines for assessment type and weightings, plagiarism, appeal process, learning objectives, use of learning tools in examination venue, invigilation, moderation, etc. Students wait up to six months for examination results. There is no defined process for students to raise concerns, grievances, or matters of unfair treatment. Little or no support exists for counselling, disabled students, or support for academically struggling or lateral entry students. There is no evidence of formal student feedback on courses, content, infrastructure, teaching staff and delivery mechanisms. 


\section{Research Capacity}

There is a willingness to engage with higher education institutions like JEC or AEC in research matters. However, these departments generally do not have access to research budgets. There is significant room to engage in aquaculture research and sustainable aquaculture, but little or no support for research funding in this area. Research capable academic staffs in AEC and JEC are unanimous in their concerns and disaffection with the expectation that they are expected to make research contributions while still carrying full teaching loads. All faculty members are fulltime teachers with a reported average of 10 hours of classroom teaching per week, with some reporting up to 19 hours teaching per week. With the support and technical staff working on civil service scheduled time, academics report that they are unable to compete with other autonomous institutes on research projects. Three main areas of concern among the research staff of AEC and JEC are:

\section{Infrastructure}

- Lack of state of the art laboratory facilities, even good labs are scarce

- College facilities remain open only during 'civil service' hours

- Lack of infrastructure facilities like power, space etc. in the Colleges

- Lack of physical infrastructure for cutting edge research

- Non-availability of equipment due to breakdowns, unavailability of outdated spare parts

- Lack of funds, modern equipment for testing and Software

\section{Funding}

- Lack of institutional funding for research work

- Lack of large research scale funding from State/Central Government

\section{Environment}

- Lack of clear policy on research activity and administrative support

- Lack of mobility to networking and expand research interest $\&$ activity
- Non- availability of sufficient Literature, online journal facilities, internet access and Software

- Work overload

\section{Assam Science and Technology University (ASTU)}

There are significant anxiety and confusion over the establishment of Assam Science and Technology University (ASTU). The vision and mission of ASTU is not clearly communicated to the Colleges. Enlisting private colleges prior to securing the buy-in of the public colleges has led to a reputational risk for ASTU. ASTU does not have an academic function yet, and there is discomfort among students in obtaining a qualification from ASTU over the long-standing degree-granting institutions such as the Gauhati University and Dibrugarh University. The Government's vision of a technical higher education model in Assam rests heavily on the success of the ASTU-Engineering Colleges relationship. It is easily possible to achieve a mutually beneficial model that delivers ASTU degrees for the Colleges with clearly defined administrative support functions from ASTU particularly on the strength of the Washington Accord accredited programs.

\section{Immediate Steps:}

The following recommendations are made to improve the technical education sector in Assam:

- Develop a Governance/Service delivery model for the Engineering Colleges for affiliation to ASTU

- Improve curriculum for the new engineering programs for rollout, including Program Educational Objectives, graduate attributes and learning outcomes

- Develop a Resource Modernisation Plan for Laboratories, Computing Centres, and Libraries including use of low cost or free Software (perhaps, open-source)

- Modify key Academic Policies, 
Procedures, Record Keeping, and Quality Assessment frameworks

- Cultivate an Industry/Community Engagement plan

- Work out a Staff Developmental Plan and supporting policies

- Develop a Student Mobility Plan, Student Experience and Wellbeing Plan

The following quick gains are possible without the requirement for major capital investment:

- Formalise affiliation of leading educational enterprises with ASTU

- Implement sanctioned staffing: $\Rightarrow$ Sanctioned posts to be filled within a specified time - for example, six months with applicants for sanctioned posts interviewed by host College

$\Rightarrow$ ASTU has already been given this power in the legislation

- Develop financial accountability:

$\Rightarrow$ Colleges to be given oneoff equipment (workshop/lab) grants to ameliorate outdated equipment

$\Rightarrow$ Facilities and facilitybased resources (power supply, data projectors, electronic whiteboards, whiteboards, etc.) to be reviewed and grants made to modernise teaching environments

- Strengthen delivery environment:

$\Rightarrow$ Learning management systems to be implemented

$\Rightarrow$ Mitigate risk especially in Health and Safety - policies to be developed implemented especially regarding laboratories and workshops

- Commence curriculum review and revision:

$\Rightarrow$ Develop course learning outcomes, unit/subject guides with clear unit learning outcomes, course learning outcomes and assessment policies for articulation/publication at the start of the session

$\Rightarrow$ Develop and implement academic integrity policies that include cheating, plagiarism and group work collaboration elements $\Rightarrow$ Colleges to assume control of setting and marking of examinations, with moderation by current Host University/ASTU during the transition period

- Improve the student experience:

$\Rightarrow$ Develop policies focusing on student interfacefeedback, quality assessment, surveys

\section{Concluding Remarks}

It is an opportune time for the Government of Assam to put the ASTU vision forward to the Colleges, so the Colleges see ASTU as the leading body in the offering, administering and managing the internationally accredited program. ASTU should also be responsible for one-stop resource delivery and governance for the Department of Education, thus substantially reducing bureaucracy. This will also allow the Government to fulfil the promises made to the Assam Directorate of Technical Education in bringing the public technical colleges to the IIT level. Furthermore, it would also be an excellent gesture by the Government to offer a quality product to the private colleges encouraging them to raise their standard.

ASTU concept is meritorious and offers significant gains for Technical Higher Education in Assam. However, the strategic leadership of ASTU has failed. Operational leadership is vague and conflicting, and ASTU is seen as an administrative watchdog, nothing else. The 
Colleges and other entities cannot make any real gains towards accreditation unless they collaborate- ASTU as the vehicle for that. Colleges feel excluded and downgraded. This must be reversed, and ASTU must become the overarching administrative entity it should be, shepherding the leading colleges to deliver an academic program that can be accredited with the NBA.

The role of ASTU and the affiliation of Colleges need to be re-engineered. This may include rebranding the two colleges for example, "University College of Assam or the University College of Jorhat" and this status for the reputable public pioneers. It is also important to define and communicate the role of Private Colleges in ASTU structure and decision-making and balance this with the role of the public colleges. One way to achieve this may be to establish ASTU Boards of Studies chaired by current College staff and with nominal private provider representative (singular) to restore the balance of power and re-invest academic leadership capital in delivery of qualifications. The current situation where there is no plan in delivering discontent, obfuscation and alienation, it is time to re-invent and re-engineer an ASTU-AEC-JEC powerhouse. Assam is ready for taking a transformational step in collaborative research and partnerships. A culture change in this regard will be of enormous benefit for the Government of Assam in transforming the technical education sector in an integrated way. 